TRAMES, 2008, 12(62/57), 2, 127-150

\title{
NEW EUROPE AND ITS NEO-REGIONALISM: A WORKING CASE OF THE 'COMMUNITY OF DEMOCRATIC CHOICE'
}

\author{
Vlad Vernygora and Natalia Chaban \\ University of Canterbury, Christchurch
}

\begin{abstract}
This paper aims to analyse the phenomenon of neo-regionalism in CentralEastern Europe (CEE) identified in this research as a phenomenon of geo-politicoeconomical co-existence that represents a new form of multidimensional integration in the chosen area. Such a definition is primarily based on the recognition of states as political actors, rather than regions within states. Given that the concept of European regionalisation has been irrevocably connected to the concept of European integration, the CEE is arguably experiencing major geo-political 'mutations'. In December 2005, several CEE states (namely Estonia, FYR Macedonia, Georgia, Latvia, Lithuania, Moldova, Romania, Slovenia and Ukraine) opted to establish a new regional political association - the Community of Democratic Choice. Our paper scrutinises this new and unique regional grouping. Is it a hectic game of political 'pigmies' intended for short-term gains in desire to 'buy' recognition from more powerful neighbours? Or is it an activity of maturing European political powers and promising markets with a long-term perspective, which perhaps could result in a more cohesive Europe (if not a more enlarged European Union)?
\end{abstract}

DOI: $10.3176 /$ tr.2008.2.02

Keywords: community of democratic choice, neo-regionalism, Europe, the European Union, former titular republics of the USSR

\section{Introduction to the issue - a semantic approach}

The European Union (EU) is an ambitious project of international integration, which has resulted in the creation of a vast geo-political region. For such a grouping to exist, its many actors - local, regional, national and supranational have to actively commit to the idea of an integrating and uniting Europe. It is a remarkable commitment, should we consider that, with the exception of supranational actors, the self-identification of other actors often occurs in terms of 
'boundaries' and 'territorial demarcation' (Gerner 1999:180). With the notion of territory being the 'very essence of the state' (Keating 1988:1), linking countries' political identity to the notions of a 'place' or a 'homeland' (Keating 1998b:3), those at the level of the nation-state may be the most cautious towards the idea of Europe. Thus, the very process of European integration is possible only if a European state shows "economic interest, relative power, [and] credible commitments" (Moravcsik 1998:4) towards its counterparts on the continent.

The key cleavages of the European identity are not confined to geographical matters only, but also include numerous linguistic, religious, cultural, historical and economical fault lines. Unsurprisingly, the modern-day EU resembles to some observers a jigsaw puzzle of several 'micro-Europes': "market Europe, social Europe, [...] wealthy Europe, poorer Europe - east and west, north and south" (Laffan 2004:77, 96). Yet, recognising that "identities may be formed around the inhabiting of a certain territory" (Chimisso 2003:45), the above listed points of divergence are argued to result in a very specific vision of Europe (and the EU for that matter); that of Europe as a collection of regions (which is different from the view of Europe as a collection of nation-states). Indeed, not only is the EU a region in itself, but it is also a place where regionalism within and across the EU Member States is a reality.

Historically, the EU's attitude to its internal regionalisation has been both accepting and supportive. In 1992, the Maastricht Treaty (or the Treaty on European Union) acknowledged the ever-present European drive towards regionalisation by formalising the establishment of the Committee of the Regions (COR). ${ }^{1}$ Presumably, this provision was intended to legitimise the importance of the regional layer in the rather complicated arrangement of EU governance. Although this layer functions below the level of nation-states, the COR also often possesses autonomous rights and powers to deal directly with the pan-European governing bodies of the EU and even foreign partners. Arguably, this original vision on internal regionalisation combines with the EU's normative point of view on the fundamental issue of the true equality that it aims to achieve, primarily by respecting "the national identities of its Member States".

Regional participation in the European project has never been 'one fit' for all. On the one hand, the phenomenon of regionalism can be found in present-day Europe within a single state locality. Some of those regions are more politically articulated and active (such as Länder in Germany or Catalunya/Cataluña in Spain). Some are less politically pronounced (such as West Sweden, East Finland or West Zealand). Yet, all of them are represented in Brussels at the level of

1 Official Website of the European Union. Available from <http://europa.eu/scadplus/glossary/ committee_regions_en.htm> [accessed 4 September 2007]. See also Maastricht Treaty, Title XVII, Chapter 4, Article 198a. Available from the Official Website of the European Union <http://eur-lex.europa.eu/en/treaties/dat/11992M/htm/11992M.html\#0098000022> [accessed 4 September 2007].

2 Maastricht Treaty, Title 1, Article F, par. 1. Available from the Official Website of the European Union <http://europa.eu.int/en/record/mt/title5.html> [accessed 20 April 2006]. 
lobbying offices (Lein-Mathisen 2004:93-114, Jones 1985:234), which pursue and keep alive the so-called 'sub-state' or 'sub-national' external relations.

In some European countries regionalism goes hand-in-hand with federalism where powerful local authorities co-exist with national ones (Keating 1998b:112115), for example, in Germany. In other cases, regionalism is interpreted as an intergovernmental cooperation across several states resulting in regional groupings within the EU (the most influential of these being the Western European Union comprised of the Benelux countries, France, Germany, Greece, Italy, Portugal, Spain and the United Kingdom). ${ }^{3}$ These state-to-state regional interactions are often conditioned by such factors as "geographic proximity...historical similarities...cultural affinity" (Pavliuk 2004:6).

The multi-levelled process of regionalisation observed in the political West of Europe is not a unique development. The post-communist territories in Central and Eastern Europe (CEE) also experienced similar geo-political evolutions. For example, several recent newcomers to the EU (namely, Estonia, Latvia, Lithuania, Slovenia and Romania), as well as few countries in the neighbourhood of the newly enlarged EU (namely, Georgia, Ukraine and Moldova) and the Former Yugoslav Republic of Macedonia (FYR Macedonia), have established a new regional political 'belt' - the Community of Democratic Choice (CDC), ${ }^{4}$ a grouping which has no analogy in the post-Cold War history of the continent.

Sceptics may contend that this new regional formation is simply an ad-hoc arrangement of Europe's political 'pygmies' who are vying for recognition of their legitimacy from their more powerful European neighbours. However, this regional grouping can also be seen as an inspiring development made by Europe's emerging political powers and promising economic markets - and as a process with a long-term perspective which, perhaps, could result in a more cohesive Europe (if not a more enlarged EU). Examining these two contradictory views, this paper attempts to explore the CDC case as an example of the processes of regional integration in the European Central-East, as well as argue its uniqueness for the ongoing project of European regionalisation.

In order to meet the above objectives, this paper firstly examines the concept of regionalism as central for this study. This concept features a "multiplicity of appearances" (Hanggi et al. 2006:7) and incorporates structures and conceptual characteristics that have evolved historically (Gullberg 1999:151). Unsurprisingly, the complex notion of regionalism, and its applications to the European/EU contexts, has captured the attention of many prominent political scholars, including Ernst Haas, Andrew Moravcsik, Michael Keating, Martin Holland, Helen Wallace and Mario Telo, among others.

Regionalism may be characterised as a process with its own stages of development and transformation. In the case of the EU, Langenhove and Costea (2007:87)

3 The Western European Union Official Website. Available from <http://www.weu.int/> [accessed 27 August 2007].

4 Official Website of the Community of Democratic Choice Youth Forum. Available from <http://www.cdcyouth.org/> [accessed 1 September 2007]. 
have argued for what they describe as the three 'generations' of regional integration: economic regionalism with its focus on "economic integration and internal prosperity of the region" (Langenhove and Costea); the post-Cold War new regionalism (also known as 'neo-regionalism') with an emphasis on bridging political elements with "deep economic integration" (Langenhove and Costea); and finally, inter-regionalism with stress on transnational connections and the "external projection of the region" (Langenhove and Costea). This last stage has also been noted in another study, where it was described as a phenomenon of "institutionalised relations between world regions" (Hanggi et al.). Adding to the discussion on the stages of regionalisation, Keating (1998b:73) claimed that new regionalism must be seen outside of the framework of the nation-states, contrasting it at the same time to 'an older provincialism'. Also there was a comment made by Telo (2006:144) that "new regional frameworks" lead to enhancing member states' commitments towards international cooperation and their transformation into "open states".

A different conceptual vision was offered by Haas (2000:446) who argued that the post-1990s world order could be described as "half-open regionalism" or simply "the coexistence of global and regional multilateral institutions and practices". Indeed, in line with Haas' comments, Europe is currently involved in two developments which are occurring simultaneously - regionalism and globalisation (Newhouse 1997). Under such circumstances, the views from Bilbo, Barcelona, München or Aiaccui are taken seriously not only at the national, interstate, or pan-European levels, but at a global level as well. The very success of the globalising economy critically depends on "specific territorial characteristics" (Keating 1998a:16).

Finally, according to Telo (106), regionalism may be studied through a dichotomy of economic and political perspectives. The economic aspect exists firstly in the form of "fragmentation relating to the global market" and, secondly, in the form of "aggregation as regards national markets" (Telo:106). The corresponding political aspect gains its strength from the "will of member states, namely the regional leaders" (Telo:106).

Taking into account the various approaches to the phenomenon of regionalism then, this paper aims to investigate the notion using the CDC case study in the context of the CEE. The study argues several unique characteristics of the regional development of the CDC, with a view to finding new conceptual challenges in the scholarship on new regionalism in Europe. One particular notion under investigation is a new form of multidimensional interstate integration in a specific area of Europe - the CEE. The key features of this regionalisation process, as well as its leading powers, are grounded within Europe's integrationist framework. In using such a framework, it is important to note that in case of the CDC, the participating states have different - sometimes incompatibly different - levels of involvement in the process of European integration.

Subsequently, four major questions guide this inquiry: What is the geo-political status of the members of the CDC community, as actors on the European political 
scene? Does any member of the CDC have the ability, or at least the potential, to lead this regional grouping, either solely or in cooperation with another state? How do the previous experiences of the CDC members in region-building activities influence this new regional grouping? and finally, What are the ultimate goals of the CDC members in participating in the CDC framework? Special attention is given in this paper to the CDC members who used to be former titular Soviet Republics. Arguably, these territories are still under-researched areas in the scholarship of neo-regionalism in Europe.

\section{The CDC: trying to outrun the past?}

Despite the fact that the process of region-building is a time- and moneyconsuming activity, it is still adamantly pursued by many international actors. Indeed, regionalisation is an ideal strategy for big powers to maximise their influence in a particular area, large or small (Pedersen 1998:3). The leading roles of the United States and China, for example, correspondingly in the North American Free Trade Agreement (NAFTA) ${ }^{5}$ and the Shanghai Cooperation Organisation $(\mathrm{SCO})^{6}$ are convincing instances of this strategy in action. Within this context, it is worthwhile noting the winning approach of Germany's "cooperative hegemony" (Pedersen:7) within the EU framework. In light of these positive examples of the strength that can be garnered through regional cooperation then, it is interesting to inquire whether the CDC offers the chance for any of its participants to enhance their own political and economic influence.

The CDC was formed on 2 December 2005, in Kyiv, Ukraine. The Declaration of the Countries of the Community of Democratic Choice was signed by a group of nine CEE states; namely, Estonia, Georgia, Latvia, Lithuania, FYR Macedonia, Moldova, Romania, Slovenia and Ukraine. ${ }^{7}$ Officially, the emphasis of the Declaration was the desire to establish a "forum of cooperation for dialogue [...] to provide support for the further economic and social development [...] and protection of the democratic process" in the vast CEE region. ${ }^{8}$

Currently, the CDC encompasses a total land mass of 1,154,118 sq. km. $(3.75$ times less than the EU) and is populated by around 88,759,000 people (5.5 times less than the EU). Analysing the profiles of the CDC participants, it is clear that

5 The NAFTA went into effect on 1 January 1994 and was signed by Canada, Mexico and the USA. Available from <http://www.nafta-sec-alena.org/DefaultSite/index_e.aspx?CategoryId=42> [accessed 3 September 2006].

6 The SCO's establishment was proclaimed in Shanghai on 15 June 2001 by six following countries - China, Russia, Kazakhstan, Kyrgyzstan, Tajikistan and Uzbekistan. Available from <http://www.sectsco.org/html/00026.html > [accessed 3 September 2006].

7 The Declaration of the Countries of the Community of Democratic Choice, signed on 2 December 2005. Available from <http://www.mfa.gov.ua/mfa/en/news/detail/1341.htm〉 [accessed 6 December 2005].

8 The Declaration of the Countries of the Community of Democratic Choice. 
each of the founding members of this sizable regional organisation would eagerly challenge its own current and rather peripheral geopolitical status quo in the CEE region in order to become a leader of this new grouping. Yet, in spite of their geopolitical ambitions, the CDC members could be described as diverse and sometimes awkward examples of a modern political Le comte de Monte Cristo; a 'prisoner' who has just 'escaped' (or almost escaped) the ubiquitous dominance of Moscow, and it is not yet known whether some of these former 'prisoners' ever had their own mentor, 'Abbe Faria', or not.

\subsection{The emergence of new European players - CDC states formally affiliated with the EU}

Four major events in the contemporary history of Europe - the fall of the Berlin Wall, the disintegration of the Soviet Union, the Balkan conflicts of the 1990s and the transformation of the European Community (EC) into the EU in 1989-1991 (Johnson 1996:282) - pushed the countries of CEE to critically re-evaluate all available possibilities for their integration with the rest of Europe. The former nonUSSR Warsaw Pact countries, as well as the three ex-Soviet Baltic Republics (Estonia, Latvia and Lithuania), indicated a strong intention to dramatically depart from their shared communist past by engaging in different 'West-\&-NATO' orientated interactions.

Estonia, for example, was one of the countries particularly determined to direct their post-Soviet development in this way. The Director General of External Economic and Development Cooperation Department of the Estonian Ministry of Foreign Affairs, Priit Pallum (2007), explicitly described his country's intentions during the post-Cold War period:

Our aim always was to regain independence, in which we succeeded after the coup in Moscow. And then, of course, what to do with the independence? The next task in the broad sense was to regain our place in Europe from which we were forcefully taken away, and to integrate into the Western European structures. Joining the EU and NATO were the two most important foreign policy goals since 1991.

This period of substantial evolution in the life of the CEE was paralleled by the EU's predecessor's frantic attempts to establish a common approach in its foreign policy and security in order to adequately respond to the changes in the CEE. The EU started visibly prioritising its natural interests in the region, at the expense it seemed, of the non-European developing world (Holland 2002:3). Delivering a speech in the Debate of the EC in House of Commons on 20 November 1991, British Prime Minister John Major (1992:428) stated that the EC's "responsibility [...] must also be to other European countries who are returning to democracy for the first time in 50 years", adding the somewhat surrealistic statement that the EC "can now plan for a European Community stretching north to the Baltic and east to the Urals". 
By 1995, this new focus in the EU's activities had resulted in the signing of subsequent association agreements with six CEE countries - firstly with Hungary and Poland, then with Slovakia and the Czech Republic, and finally with Bulgaria and Romania. These six CEE states were eager to move behind the newly-emerged and highly-lucrative "Golden Curtain" (Johnson:284) of the democratic and prosperous EU. The post-Soviet Baltic States as well as the post-Yugoslavian 'success story' Slovenia (a country that prefers to stress its Alpine and Central European, but not its Balkan heritage"), had a similarly warm reception from the $\mathrm{EU}$, although their agreements were slightly delayed in ratification.

For the chosen CEE states, signing EU-orientated agreements meant not only that their road to the West was at last being mapped, but more significantly, their presence and right to act within the Western political sphere was accepted by the EU. It also meant a definite departure from their troubled past and the erasing of some long-lived ideological prejudices.

For the West, it seemed that there could hardly be better time for reconciliation with the East. The USSR, the power against which the Western democracies had long situated themselves, disappeared from the world's political map de facto on 1 December 1991 (Bremmer and Taras 1993:95). In the same year, the establishment of the 'Weimar Triangle' with Germany, France and Poland as its members ${ }^{10}$ illustrated the fact that the developed democracies of Europe had recognised the emergence of the new CEE political actors on the continent (specifically, in this case, Poland).

At the beginning of 1991, on February 15, Czechoslovakia, Hungary and Poland established another regional grouping within the CEE known as the Visegrad Group. ${ }^{11}$ Using the countries' shared medieval historical motif as a background for unity, this sub-regional body was formed to become a 'foundation study institution' for the inexperienced but ambitious states who wished to participate in the EC and NATO. In the very same period, Estonia, Latvia and Lithuania also combined their efforts and established the Baltic Assembly; a subregional parliamentary consultative organisation, which encompassed a clear Western-orientated political vector. ${ }^{12}$

These and many other regional interactions ultimately contributed to the accession of CEE states to the EU: Estonia, Hungary, Latvia, Lithuania, Poland, the Czech Republic, Slovakia and Slovenia all became EU Member States on 1

9 'When Small Is Beautifully Successful', The Economist, 13 October 2005. Available from $<$ http://www.economist.com/research/articlesBySubject/displaystory.cfm?subjectid=9500010\&st ory_id=E1_VDNVSPS $>$ [accessed 7 April 2007].

10 'The Weimar Triangle', available from France Diplomatie <http://www.diplomatie.gouv.fr/en/ country-files_156/germany_335/the-weimar-triangle_3451/index.html> and <http://www. diplomatie.gouv.fr/en/country-files_156/poland_347/index.html> [accessed 20 August 2006].

11 The Visegrad Group Official Website. Available from <http://www.visegradgroup.org/main.asp> and <http://www.visegradgroup.org/main.asp?MainOblID=15742> [accessed 20 August 2006].

12 The Baltic Assembly Official Website. Available from <http://www.baltasam.org/?CatID=26> [accessed 9 September 2006]. 
May 2004, and Romania and Bulgaria on 1 January 2007. FYR Macedonia has also been recognised as an official EU candidate although an accession date is yet to be established.

Having then already joined the EU or, in the case of FYR Macedonia being officially invited to eventually do so, what do the three Baltic States, Romania, Slovenia and FYR Macedonia hope to achieve in the establishing of the CDC with such partners as Moldova, Ukraine and Georgia? This paper argues a set of reasons why these countries entered the CDC arrangement.

Firstly, with the common goal of all CDC participants being to rid themselves of their common 'communist' past, yet another forum to "promot[e] and strengthen[..] the core democratic principles and practices"13 is seen as a highly beneficial exercise. Tackling their democratic deficiencies is a paramount issue for majority of the CDC participants, including those who have already met the 'Copenhagen Criteria' in order to enter the EU. Prior to joining the EU, the Baltics, Slovenia and Romania had to (as will FYR Macedonia) provide sufficient evidence that their state institutions were or are capable of guaranteeing democracy, the rule of law, human rights and the respect for and the protection of minorities..$^{14}$

In this context, the more democratically advanced CDC members (namely, Estonia, Latvia, Lithuania and Slovenia) have realistic opportunities to lead the CDC region by example. Estonia already occupied the world's top ranking in the inaugural 2006 'State of World Liberty Index'; a classification that combined several respected data sources related to such matters as individual freedom, economic freedom, government size and taxation, economic equality, among others. ${ }^{15}$ A Vilnius Conference in May 2006, entitled 'Common Vision for Common Neighbourhood' and jointly organised by Lithuania and Poland, made headlines around the world and specifically stressed the need to welcome "the initiatives to expand cooperation across Europe" and "promoting European and transatlantic integration"16 in the region. In October 2007, Lithuania and Poland organised another international conference in the Lithuanian capital - the 'Vilnius Energy Security Conference'. This event had a similarly high resonance worldwide and was primarily dedicated to the "challenges and opportunities in shaping the global and European energy landscape". ${ }^{17}$

13 The Declaration of the Countries of the Community of Democratic Choice.

14 'The 1993 Copenhagen Criteria'. Available from the Official Website of the European Union <http://europa.eu.int/information_society/activities/atwork/_documents/dgenlargementbrochure/s ld005.htm> [accessed 20 September 2006].

15 'The 2006 State of World Liberty Index'. Available from The State of World Liberty Project Official Website <http://www.stateofworldliberty.org/report/arankings.html> [accessed 9 September 2006].

16 'Joint Communiqué', accepted on 4 May 2006 in Vilnius, Lithuania. Available from the Vilnius Conference'06 Official Website <http://www.vilniusconference2006.it/sen/news.full/54?prn=1> [accessed 5 May 2006].

17 Vilnius Energy Security Conference 2007 Official Website. Available from <http://www. vilniusconference2007.lt/en/apie> [accessed 25 October 2007]. 
Secondly, the CDC is likely to be useful for the EU newcomers to represent themselves as capable sources of knowledge about the CEE region. Indulis Bērziñš (2007), the Latvian Ambassador to the UK, Australia and New Zealand and the former Minister of Foreign Affairs of the Republic of Latvia, stated that Latvia "see[s] ourselves as experts in the area"; an area which covers the postSoviet states of Belarus, Ukraine, Georgia, Azerbaijan and Moldova. Bērziņš (2007) concluded that it is in Latvia's interests "to see a positive development in all these countries". Reiterating his Latvian counterparts' sentiments, Priit Kolbre (2005:32), the then Chancellor of the Estonian Ministry of Foreign Affairs, expressed the opinion that his country has "been able to contribute [...] to the European Union's common policy as far as relations with Russia are concerned". The Estonian diplomat also noted that "eastern European countries have much greater expertise than those on the western side" (Kolbre) when it comes to understanding Russian-related issues.

Thirdly, the CDC is likely to raise the profiles of its members in Europe and worldwide. For example, the Baltic States have been facing the challenge within the European Union of being virtually unknown to the 'old' EU-15 in terms of their national characteristics and peculiarities. In addition, while the EU's developed democracies are relatively secure with the 'less-sovereignty' and 'moresupranational-institutions' arrangements within the Union, its new Member States still require some recovery time after the secondary status they had during the Soviet domination in their region. As such, for those countries who are already EU Member States, the CDC forum provides the unique opportunity to belong to a circle of countries who share similar national sentiments, as well as allowing them to act on the world stage outside of the EU for a little longer.

The need to be distinguished is also very much relevant to FYR Macedonia. Its rather complex relations with neighbouring countries (Albania, Bulgaria and especially Greece and the newly independent Kosovo) make it necessary for FYR Macedonia's originality and uniqueness to be pronounced more clearly and on the regional level (distinctly different from the country's traditional regional vectors). This emphasis may then prove useful for allowing FYR Macedonia's voice to be heard while it continues working towards solving the Kosovo crisis, for example, as well as in the process of obtaining an invitation to join NATO or during the yet to be started pre-accession negotiations with the EU. Indeed, all of these opportunities were noted by Branko Crvenkovski (2007), FYR Macedonia's current President, when delivering his speech at the $62^{\text {nd }}$ session of the General Assembly of the United Nations.

Fourthly, with all CDC members striving to improve their economic standards, the strong economic agenda which underpins the CDC framework may be another point of attraction for the EU 'neophytes'. The grouping could be instrumental in realising an opportunity for ultimately gathering the Baltic-Black-Caspian Seas countries under one economic 'umbrella'. A desire to be less dependent on Russian-supplied gas and oil, the need to economically stimulate ports on the Black and the Baltic Seas, as well as on the Danube and the Dnieper rivers, and 
the operational requirement for a trustworthy community-oriented regional organisation - these are the leading economic principles which drive the EU newcomers towards active participation in the CDC.

\subsection{The emergence of the new European players - CDC members participating in the $C I S$}

Aside from the three Western-oriented Baltic States (once called "Western enclave within the multi-national Soviet state" (Misiunas and Taagepera 1993:1)), other former Soviet titular republics moved in a different direction of regional integration after gaining their independence in 1991. After the end of the Gorbachev era that eventuated with the collapse of the Soviet communist empire, some of the newly independent states suddenly made a step backwards, to a political environment of 'us' and 'them'.

In December 1991, Belarus, Russia and Ukraine initiated the establishment of the Commonwealth of the Independent States (CIS).${ }^{18}$ From its inception, the CIS was no more than an initial effort to soften the pain of 'divorcing' the empire - a swift and populist gesture that was aimed simply at stopping the structural economic decline of the former Soviet Union. Interestingly, although the CIS arrangement may have held some short-term benefits for the former USSR states, including the Baltic States, but the ever-present "fear of Russian domination" ultimately caused the Baltic group to resist entering the Commonwealth (Dreifelds 1996:11). For three members of the CIS though - Ukraine, Georgia and Moldova - joining the new regional grouping of the CDC held many incentives. This paper now turns to the opportunities and challenges provided by this further regionalisation.

\subsubsection{Ukraine}

Until the 'Orange Revolution' in 2004, Ukraine, one of the three largest Eastern Slavic states in the CEE region, remained, according to Robinson (2004: 191), "largely isolated from the wider world", being focused on its "unsatisfactory mutual relations" with other members of the CIS, particularly with the Russian Federation. Entering the CIS agreement was a clear indication of the Ukrainian 'new-old' political elites' inability to prioritise European perspectives for their country.

In 1991, a German study evaluated Ukraine's coefficient of potential integration to the European economy as 83 points out of 100 (the leading place among other post-Soviet countries); in contrast, the Baltics obtained only 77 points each (Motyl and Krawchenko 1997:246). However, this potential, a promise of prospective European integration, was wasted. The Ukrainian establishment at the

18 The Executive Committee of the Commonwealth of the Independent States. Available from <http://www.cis.minsk.by/main.aspx?uid=74> and <http://www.cis.minsk.by/> [accessed 7 September 2006]. 
time instead favoured an orientation towards the CIS, led by Russia; a choice which arguably contradicted the Ukrainian public opinion which was overwhelmingly independence-orientated. ${ }^{19}$

The Ukrainian case becomes even more complicated when it is considered that the European West proved to be unprepared to deal with a large and newly independent polity with a landmass the size of Germany and the UK combined. Stefan Meller (2006), the former Polish Minister of Foreign Affairs, noted that there was not a single political scientist who could predict at that time that an independent Ukraine could be established. Arguably then, the momentum for Ukrainian integration with Europe was lost not only by the Ukrainian side, but by the EU as well.

Rather discouragingly, Ukraine's first attempt at acting as a regional player outside of the CIS was not a success story. On 25 June 1992, it was one of the eleven founding signatories of the Black Sea Economic Cooperation (BSEC) $;^{20} \mathrm{a}$ promising, but operationally cumbersome organisation established by the countries of the Black Sea region (including Georgia and Moldova). ${ }^{21}$ The goals of this organisation included fostering interaction between its members, ensuring peace and encouraging friendly relations in the region. Despite these noble tasks and contrary to the obvious geo-political benefits that such a grouping might have generated, the BSEC has not been fully recognised as a working region by the wider world (Pavliuk:7).

Alternatively, in 1997, the independent Ukrainian state, together with Georgia, Moldova and Azerbaijan, was involved in establishing yet another regional grouping - the GUAM group; ${ }^{22}$ a US-backed consultative body. Similarly to the BSEC, this grouping was initially treated by outsiders with a degree of scepticism, however it gained more serious consideration after the Ukrainian democratic 'Orange Revolution' and the so-called 'gas wars' with Russia that followed. Being supported (or perhaps influenced) by Georgia, Ukraine began playing the GUAM card in its search for alternative (non-Russian) energy suppliers (primarily, from the oil-rich Azerbaijan).

Almost inevitably, Ukraine's 'regionalising' attempts have been scrutinised through the prism of the position of the Russian Federation, the country's largest

19 On 1 December 1991, the former Soviet Republic of Ukraine overwhelmingly, by $90.3 \%$, voted in favour of its independence from the USSR. See: Ukraine Today Website, <http://www. ukraine-today.com/reference/facts/16.shtml> [accessed 27 April 2006].

20 Official Website of the Black Sea Economic Cooperation. Available from <http://www.bsecorganization.org/main.aspx?ID=About_BSEC> [accessed 1 August 2007].

21 As of 2007, BSEC members include Albania, Armenia, Azerbaijan, Bulgaria, Georgia, Greece, Moldova, Montenegro, Romania, Serbia, Russia, Turkey and Ukraine.

22 The organisation's acronym was made out of the first letters of the following countries' names Georgia, Ukraine, Azerbaijan and Moldova. See: Official Website of the GUAM, available from <http://www.guam.org.ua/211.0.0.1.0.0.phtml> [accessed 10 September 2006] and 'General Information about GUAM', available from the Ministry of Foreign Affaires of Georgia Official Website < http://www.mfa.gov.ge/index.php?lang_id=ENG\&sec_id=129\&info_id=1497> [accessed 10 September 2006]. 
and increasingly assertive south-eastern neighbour, and compared to the stance of Ukraine's neighbour to the north, Belarus. Neither Russia nor Belarus are members of the CDC, yet their aspirations in terms of regional construction must be considered here since they influence the formulation of Ukraine's priorities in the wider CEE region, and even internationally.

The Republic of Belarus has acquired a status of 'semi-sovereign state' by being entangled in the Belarus-Russia dyad and counting (depending) on Russian oil and gas to fill the country's pipelines (Hancock 2006:120-121). Until recently, a political "Union with Russia" was formulated as one of the main principles of Belarus' foreign policy. ${ }^{23}$ Such a union was seen as being able to provide a possibility, albeit a remote one, for the Belarusian President to become a rotational leader of the two unified countries. However, the current political regime in Moscow is clearly uninterested in sharing its sovereignty with any other political entity.

At present, Belarus refrains from moving politically closer to Poland and Ukraine in order to possibly establish a strong geo-economical triangle of the main European energy-transit countries (Mostova 2007). Very much on the contrary to closer CEE integration, President Alyaksandar Lukashenka has been leaning towards enhanced interactions with the South American state of Venezuela. In June 2007 in Minsk, the Belarusian leader told Venezuelan President Hugo Chavez that the two geographically remote countries shared "absolutely identical" 24 views on international affairs, and it could be treated as "a reliable basis for close cooperation and mutual support in the international arena". ${ }^{25}$ In this context, Belarus' prospective participation in a European democratic regional grouping becomes ever-more remote.

A distinctively regionalised country in itself, the Russian Federation occupies a separate place in the discussion on regionalisation both in the CEE and in the former Soviet Union space. It launched the 'empire-keeping' game almost immediately after the collapse of the USSR (even though Boris Yeltsin, the first Russian President, had himself critically contributed to the process of demolition of the Soviet Union $^{26}$ ). Despite the fact that Russia was intimately influenced by the disappearance of its super-power status, with time the country has found it both logical and politically rewarding to use a new 'trump card' - its role as one of the world's main energy-suppliers.

From a regional perspective, the Russian Federation is likely to push hard for the creation of a common Russian-led economic space in the post-Soviet area

23 'Belarus Foreign Policy Priorities', available from The Official Internet Portal of the President of the Republic of Belarus (Russian language version) <http://www.president.gov.by/ press23865.html> [accessed 10 September 2006].

24 'Belarus, Venezuela to Sign 1-bln-Dollar Contracts', 23 July 2007. Available from <http:// news.xinhuanet.com/english/2007-07/23/content_6418529.htm> [accessed 1 August 2007].

25 'Belarus, Venezuela to Sign 1-bln-Dollar Contracts'.

26 The Russian Federation proclaimed its independence on 12 June 1990 prior to Ukraine (16 July 1990) and Belarus (27 July 1990). 
(Illarionov 2005). The Eurasian Economic Community (Eurasec) ${ }^{27}$ a replica of the former European Economic Community, is a working example of such initiatives. On 6 October 2007, in the Tajik capital Dushanbe, three of the five signatories of Eurasec (namely Belarus, Kazakhstan and Russia) declared a consensus on the establishment of a Customs Union amongst them by $2011 .{ }^{28}$ Moreover, Moscow does not hide its close and ongoing interactions with several of the breakaway territories of Georgia and Moldova (namely, Abkhazia, South Ossetia and the Transdniestria). Also, at the beginning of the 1990s, together with the preLukashenka Belarus - a young but increasingly weakening democracy - Russia could not have conceived of the existence of the CIS without Ukraine (Bukkovol 1997:63). Thus the Ukrainian 'Orange Revolution' was treated in the Russian capital as a humiliating and largely personal rebuff to the then Russian President Vladimir Putin. ${ }^{29}$ Predictably, Russia has used its influence to facilitate the 2008 decision of the NATO summit in Bucharest to drop off Ukraine's and Georgia's bids to join the Alliance.

If compared with its two post-Soviet CEE Slavic counterparts, Ukraine seems to be if not less corrupt, then at least more advanced in understanding and exercising the rules of democracy. ${ }^{30}$ Its interest in participating in the CDC is suggested to be supported by several following factors. Firstly, Ukraine's membership in the CDC (as well as in GUAM) can be seen as another incentive to eventually leave the Russian-led CIS, a "loose non-state association" (Nahaylo 1999:452) that is "not [...] an effective vehicle for cooperation in the post-Soviet space" (Robinson:185). Within the CIS framework, Ukraine has always remained "cautious" (Bukkovol:64) with regards to most integrative initiatives, and its participation in new democratic regional groupings without Russia's dominating presence could ultimately serve as another step towards Europe.

Secondly, for the economically-advancing Ukraine, the CDC could be seen as a 'playground' for interactions with territories that are already in the EU. In this light, the CDC serves as a bridge for reaching the EU and for establishing longterm business connections there. The level of Ukraine's economic interactions with the EU have grown substantially - by 1 July 2006, the EU had directly invested \$US 13.5 billion into the Ukrainian economy. ${ }^{31}$ Despite Ukraine's slow

27 'Agreement on Foundation of the Eurasian Economic Community', signed on 10 October 2000 in Astana, Kazakhstan. Available from <http://www.worldtradelaw.net/fta/agreements/ eaecfta.pdf> [accessed 9 October 2007].

28 'Customs Union Agreement Signed at Eurasec Summit', 6 October 2007. Available from the Russian News and Information Agency NOVOSTI Official Website <http://en.rian.ru/ world/20071006/82737906.html> [accessed 12 October 2007].

29 'Putin's Power Play', The Press, 6 January 2006, A8.

30 At present, Ukraine occupies the world's $50^{\text {th }}$ place in the list of the 'Individual Freedom Index' and $87^{\text {th }}$ place in the list of the '2006 State of World Liberty Index' against Russia's $112^{\text {th }}$ and $124^{\text {th }}$ and Belarus' $128^{\text {th }}$ and $153^{\text {rd }}$ places. See: 'The 2006 State of World Liberty Index'.

31 State Statistics Committee of Ukraine Official Website. Available from <http://www.ukrstat. gov.ua> [accessed 23 September 2006]. See also Korrespondent News Portal <http://www. korrespondent.net/main/164948/> [accessed 23 September 2006]. 
political progress, whereby it is considered to be only "halfway along the road from Soviet totalitarianism to full democracy" (Wagstyl and Olearchyk 2007), and despite the "lethargy" (Wagstyl and Olearchyk 2007) of some of the country's prominent democratic politicians, including President Yushchenko, the high volume of the EU's direct investments may indicate that Ukraine is becoming a more lucrative market for the Union. The level of Ukraine's functional capacity to successfully co-host the European Football Championship in 2012, a major European sporting event, can answer a few integration-related questions, too.

Thirdly, its participation in the CDC may earn Ukraine the reputation of being a reliable and enthusiastic political partner; an important image for attracting external supporters for Ukraine's perspective bid for EU membership. One such supporter (if not the main one) is Poland; a powerful 'behind-the-scenes' player in the geo-political 'sandpit' of the CEE. In spite of the fact that the Polish state is not a formal member of the CDC, a strong Polish-Lithuanian axis within the EU makes and will continue to make a significant impact on the CDC activities. While emphasising that "everything is in the hands of the [new/young civil] societies of Eastern Europe and their leaders", Polish President Lech Kaczynski and Lithuanian President Valdas Adamkus (2006) stated that "[i]t is our moral duty to work for the enlargement of the Union".

Fourthly, the CDC could prove to be a training ground for Ukraine to exercise regional leadership. The post-'Orange Revolution' Ukraine, the largest country located on the European continent, has had a semi-successful attempt at distinguishing itself from its own image of a totally corrupt quasi-state. The valid arguments that Ukrainian President Viktor Yushchenko has "failed to take full advantage of his Orange Revolution triumph" (Wagstyl and Olearchyk), do not necessarily undermine the possibility for Ukraine to become a regional leader either in a strong alliance with another country (i.e. Poland, Georgia or Lithuania) or even on its own. According to the International Election Observation Mission, the most recent parliamentary elections in Ukraine, which took place on 30 September 2007, "were conducted mostly in the line with international commitments and standards for democratic elections". ${ }^{32}$ Considering the country's infamous portrait in the past, its present capability to organise democratic elections for the third consecutive time since 2005 can arguably be treated as a promising factor for Ukraine to become an experienced regional democracy with the time.

\subsubsection{The Caucuses and Moldova}

The two other former USSR members of the CDC are Moldova and Georgia. In contrast to their Eastern Slavic counterparts discussed above, the former titular Soviet Republics of Georgia and Moldova (on par with Armenia and Azerbaijan) have survived the turbulent 1990s; a period of economic decline and "the decade

32 'Ukraine's Elections Open and Competitive but Amendments to Law of Some Concern, International Observers Say'. Available from <http://www.osce.org/item/26824.html> [19 October 2007]. 
of nationalism" (Haas 1997:vii), during which they experienced violent ethnic conflicts and civil wars.

Moldova, an artificial nationhood created in 1940 by the Soviet Moscow, experienced one of the bloodiest post-Soviet civil wars. In 1992, the predominantly Slavic Transdniestrian separatists revolted against the central Romanian-speaking authorities located in the capital Chisinau (Freire 2004:202). To some extent, the outcome of the conflict was influenced by "Russian military forces intervene[ing] on the side of the Transdniestreans" (Freire:202), and the overall situation can be characterised by "the uncompromising stances" (Freire: 203) of the three sides involved: the Transdniestrian breakaway territory, Moldova and the Russian Federation.

Armenia and Azerbaijan also followed the path towards civil war - the two were considered to be the worst examples of Soviet activity in boundaries' delimitation, ${ }^{33}$ which resulted in military conflict between the two countries and many casualties on both sides. Georgia, too, with its multiethnic composition was also embroiled in a series of violent conflicts inside the state.

At present, the separatist regions in Georgia (the Republic of Abkhazia and the South Ossetia), Azerbaijan (the Republic of Nagorno-Karabakh) and Moldova (the Transdniestria) do not have their own official representation at the United Nations (UN), yet they seem to have become more than just "Ruritanian fantasies" (King 2004:21). For example, on 17 September 2006, 77.6 per cent of the Transdniestria's eligible voters participated in a consultative referendum, and 97.1 per cent of those participants voted in favour of Transdniestrian independence from Moldova and the following Transdniestria's free accession to the Russian Federation. ${ }^{34}$ The pre-referendum campaign in Transdniestria was characterised by billboards which frankly and rather proudly claimed, "[w]e remember: we are not Moldova", and glossy leaflets with images of the Russian passport on them (Het'manchuk 2006).

Such political turmoil became more visible after a similar referendum in the other Russian-supported area, the South Ossetian region of Georgia. The event occurred on 12 November 2006, and the people of the South Ossetia were asked: "Do you agree that the Republic of South Ossetia should retain its current status as an independent state and be recognised by the international community?" (Socor 2006). The de facto authorities claimed that 52,000 people out of 55,000 eligible voters had voted, and 99.9 per cent of them answered 'yes' to the question (Socor).

33 On 5 July 1923, the Soviet central power "awarded" the region of Nagorno-Karabakh with its majority of Armenian population (around 70 per cent) to Azerbaijan. The legitimacy of such a 'grant' was never accepted in Armenia, and, since 1960s, the situation "became progressively worse" that later led to a military conflict between the two nations after the collapse of the USSR (Hunter 1993:246-247).

34 'Majority of Inhabitants of the Transdniestria Have Voted for Independence and Union with Russia', 18 September 2006. Available from NEWSru.com <http://newsru.com/world/ 18sep2006/refer_print.html> [accessed 18 September 2006]. 
In spite of the tragic and destructive developments in the 1990s, Armenia, Georgia, Moldova, and to some extent Azerbaijan all possess significant potential for democratic and economic revival. The Caucasian countries' profiles all contain unique historical connections to the 'Europeanness'. Armenia, for instance, was the first polity to adopt Christianity at the level of the state in the $4^{\text {th }}$ century (Dudwick 1993:261). Georgia followed its south-eastern neighbour two centuries later. During Soviet times, the Georgian Republic had an informal leading role in the sub-region of the South Caucuses, which arguably developed due to the support rendered to the Republic by some highly influential Soviet leaders. ${ }^{35}$ At present, the newly independent Georgia, still struggling to recover from its violent domestic conflicts, aspires to lead its sub-region within the CEE and takes a distinctly pro-European orientation. These European ambitions have grown remarkably after the democratic 'Rose Revolution' of 2003 and after Georgia's President Mikhail Saakashvili was elected in 2004. According to the "Georgian Foreign Policy Strategy for 2006-2009", the country's intentions will increasingly move towards becoming "a European State with strong institutions, fully integrated into European and Euro-Atlantic structures" (Bezhuashvili 2006).

As different 'coloured' revolutions are happening in the former Soviet Republics (more specifically, the 'Orange Revolution' in Ukraine and 'Rose Revolution' in Georgia), and as the former Republics' continue to be dependent on Russian-supplied oil and gas, regional organisations such as GUAM have emerged. Indeed, GUAM's status was reinforced in May 2006 when it was upgraded to the 'Organisation for Democracy and Economic Development GUAM' ${ }^{36}$ Georgia has assumed a leading role within the 'made-over' organisation.

Georgia's Caucasian partner in the GUAM is Azerbaijan - certainly a key player in the region, particularly since the launch of the Baku-Tbilisi-Jeikhan oil pipeline. This British-Azeri-American-Norwegian-Turkish-French-Italian-Japanese joint venture marks the culmination of a 10-year high-level political controversy as the pipeline began supplying Azeri and Kazakh oil through the territory of Azerbaijan, Georgia and Turkey, thus bypassing entirely the Russian Federation (Makhmudov and Zygar 2005). By launching the Baku-Tbilisi-Jeikhan pipeline, both Azerbaijan and Georgia have arguably made their 'premiere debut' on the stage of the global economy.

Unlike the two Caucasian states of Georgia and Azerbaijan, Moldova does not have rich mineral resources or a history of sub-regional leadership and relative economic prosperity under the Soviet regime. A small country sandwiched between the much larger Ukraine and Romania, Moldova has had little attention from most European actors outside of its region. Economic hardships, ethnic conflicts and incompetent governance make Moldova an unlikely candidate for a

35 Soviet dictator Joseph Stalin (1878-1953) and the NKVD chief Lavrentiy Beria (1899-1953) were of Georgian descent.

36 'General Information about GUAM'. 
quick accession to the EU, unless it eventually becomes an autonomous region of Romania. According to Spiegel, by the end of 2007 "almost 40 percent of all Moldovans will have applied for [Romanian] passports - some 1.5 million people out of a population of 4 million". "Yet, Moldova's geo-strategic importance (situated almost in the middle of the European continent) does attract the attention of its larger neighbours when it comes to regional integration in CEE. Additionally, Moldova is actively participating in the European Neighbourhood Policy - its Action Plan for Moldova was adopted in February 2005. At this stage, the EU has officially noted Moldova's elements of progress, especially in regards to the management of the Moldova-Ukraine border and in the area of trade. ${ }^{38}$

Out of the four states considered here, however, only Georgia and Moldova have joined the CDC; Azerbaijan is only associated to the organisation as an observer. Several reasons are argued to have guided Georgia and Moldova's decisions to join the budding regional grouping. Firstly, the CDC could be viewed by the two states as yet another mechanism in resolving the ongoing issues surrounding the currently 'frozen' ethnic conflicts on their territories. Encouragingly, the cease-fire status quo has been maintained, but the breakaway territories require urgent attention in terms of their political and economic development. Speaking on behalf of the then UN Secretary General Kofi Annan, UN Assistant Secretary General Kalman Mizsei (2005) noted that the UN Development Programme (UNDP) will be working with the CDC towards achieving the Millennium Development Goals (namely, eradicating poverty and hunger, promoting gender equality and ensuring environmental sustainability) in the region. Moreover, with Georgia, Moldova and Ukraine also being members of GUAM, CDC could arguably piggy-back on the GUAM proposition to discuss the 'frozen' regional conflicts within the context of international piece and security. Indeed, this issue received global consideration when included on the agenda of the $61^{\text {st }}$ Session of the UN General Assembly. ${ }^{39}$

Secondly, CDC is considered to be a tool for establishing contact with the Caspian Sea region; one of the richest areas in mineral resources (and oil in particular), and an area that requires extensive further democratic development. ${ }^{40}$ The '2006 Economist Democracy Index', for example, placed Azerbaijan within the group of authoritarian regimes, ranking it $129^{\text {th }}$ from the total number of 167 in

37 'Hundreds of Thousands Would Rather Be Romanian', Spiegel Online International, 8 March 2007. Available from <http://www.spiegel.de/international/0,1518,470666,00.html> [accessed 15 May 2007].

38 ENP Progress Report - Moldova, 2006. Available from <http://www.delmda.ec.europa.eu/ eu_and_moldova/pdf/061129_progress_report_final_en.pdf> [accessed 23 August 2007].

39 Novosti - Grusiya Informational Agency Official Website. Available from <http://www. newsgeorgia.ru/geo1/20060914/41806842-print.html> [accessed 15 September 2006].

40 The Declaration of the Countries of the Community of Democratic Choice. 
terms of its democratic development. ${ }^{41}$ The CDC inaugural Declaration clearly identified that the organisation's relations with Azerbaijan are one of its political and economic priorities. ${ }^{42}$ Politically, the CDC may be of some help to the Caspian nation in the process of becoming more democratic and transparent. Economically, cooperation with the Caspian region may be beneficial in terms of decreasing the CDC members' dependency on Russian oil and gas.

Thirdly, cooperation with the double 'hatted' CDC members/current EU members, who are ethnically and geo-politically close to the non-EU states in the CDC may be a good opportunity for some CDC members to progress economically and in some cases also politically. In particular, Romania's involvement in the CDC framework could be a crucial input into the formulation of Moldova's European perspectives, in whichever direction these might be. Romanian President Traian Băsescu (2007) noted that " $[t]$ he population of Romania and the population of the Republic of Moldova have the same history, speak the same language, have the same culture"; he also expressed his country's intention "to provide assistance [...], so the Republic of Moldova returns to Europe". This arguably indicates that the Moldovan state, provided it becomes more experienced in international politics, more peaceful and more democratic through its participation in the CDC, may be a trump card for Romania as it plays the bargaining game for regional leadership.

\section{Discussion and conclusions}

As has been seen, the new European players - countries from Central and Eastern Europe - are willing participants in the framework of regionalism, and each of these actors ultimately aspires to lead its sub-region. This paper has examined a new grouping in the CEE region - the CDC. The study separately considers two groups of actors in this new organisation, arguing that different goals were pursued by the members of each group in their accession to the CDC.

The first group consists of the new EU members and an approved EU candidate coming from the CEE region. The second group is comprised of the former titular parts of the Soviet political empire, which emerged as independent political entities after the collapse of the USSR. The latter CDC members are not yet members of the EU and have not yet officially negotiated their future within the EU. Also, the latter group has been internally sub-divided, distinguishing Ukraine, a large Eastern Slavic state, from the Caucuses and Moldova.

Regardless of these different motifs subjectively standing behind the creation of the CDC, the group is objectively argued to be yet another opportunity for all participants to exercise political and economic leadership in sub-regional

\footnotetext{
41 'The Economist Intelligence Unit's Index of Democracy'. Available from <http://www. economist.com/media/pdf/DEMOCRACY_INDEX_2007_v3.pdf> [accessed 17 July 2007].

42 The Declaration of the Countries of the Community of Democratic Choice
} 
formations outside their own boundaries. Indeed, a wider CEE region may already have a leader - Poland, the largest country from the twelve recent newcomers to the EU. It has a long tradition of democratic practice, it was one of the first three statehoods to adopt a constitution (Dembinski 1941:133-135), and the Polish state is currently profiled as a young, active civil society, which chose the EU membership as a 'not-to-be-missed' chance to return to Europe. ${ }^{43}$ Since Poland is not a member of the CDC, the organisation therefore offers a prime opportunity for other CEE actors to try on the leadership 'hat' in their region. As this paper argued, Estonia, Latvia, Lithuania, Georgia and Ukraine are all motivated to become such leaders.

Another CEE state, Slovenia, had a unique chance to showcase its leadership capabilities when it takes the presidency of the Council of the EU from January to June 2008. Back in 2005, according to The Economist, Slovenia, the per capita richest country in the ex-Communist Europe, was engaged in informal and friendly competition with Estonia, the then fastest growing economy in Europe. It was a rare example when a post-Communist state considered "learning from another country" ${ }^{44}$ without insisting on the uniqueness of its problems.

The goal of this paper was not only to present and describe the statehoods which emerged from the ruins of communism in CEE, but also to highlight some rather unique conceptual characteristics of the multidimensional integration in the region using the example of the CDC. This paper argues that such a "regional arrangement" (Wallace 2002:137) could indicate a new form in the regional developments of Europe - an extended period of new regionalism. The evolution of this phenomenon is suggested to face of several challenges in its existence; namely, theoretical, structural and operational.

Commenting on the theoretical dimensions, it is important to note that the CDC case of regionalisation is occurring in an ambivalent environment originating from the fact that this area of Europe used to be "highly centralised" (Gerner:183) in the past. Six out of the nine founding members of the CDC were former Republics of the USSR, an entity which was once sharply described as a "parody of federalism" (Prizel 1998:184). Three other members were also members of the "socialist camp' controlled by the Kremlin after World War II. Undeniably, "shared identities" (Herrmann and Brewer 2004:1) are already in place for most of the CDC members, thus, the promotion and development of "cross state cooperation on a series of functional matters" (Herrmann and Brewer) could prove very efficient. The CDC, on par with GUAM and the two aforementioned 'Vilnius Conferences', could be cited then as examples of neo-functionalism in current regional relations in the CEE. Yet, a shared legacy of being 'under the heel' of a big empire in their recent history also leads to an opposing and persistent trend. At present, every member of the CDC (and CEE for that matter) tends to overemphasise its national

43 In June 2003, Poland voted to join the EU by 77.45 per cent to 22.55 per cent (Szczerbiak 2004:266).

44 'When small is beautifully successful'. 
characteristics and sovereign identifications - a natural reaction to the Soviet dominance in the region, marked by the secondary status assigned to the notion of national distinctions (especially within the USSR). This clash between neofunctional uniting vectors and the nationalistic separatist tendencies is potentially ripe with conflicts when a new, rather amorphous regional organisation begins to look for firm commitment from its member states.

For the structural dimensions, the CDC members may encounter difficulties and potential conflicts on both the micro- and macro-levels of their policy making. Addressing the micro-level, it is clear that interactions within the CDC are being implemented on an intergovernmental level, not yet on the level of cross-border cooperation between the states. Additionally, some of the parts within those members are decisively leaning toward separatism, and thus there is a threat that a stable intergovernmental framework of a wider regional cooperation could be blocked.

At the macro-level of interactions, all CDC members are relatively new on the global stage, and this novelty may also impede the path towards a more efficient regionalisation. Only Romania and Ukraine were members of the UN prior to 1991, however, Moscow always exercised a strong control over the UN activities of these two states - their foreign offices were simply informal branches of the Soviet Ministry of Foreign Affairs (Galaka 2002:85). Predictably, there is always a risk that the CDC members' emerging foreign policy priorities may clash with the interests of the new regional grouping.

A possibility of discord may also emerge on the operational side of the process, with the CDC members simultaneously participating in the various regional bodies. The two main 'clubs' to which the CDC members belong are the EU (the three Baltic States, Romania and Slovenia being members, and FYR Macedonia being accepted as an accession candidate) and the CIS (Ukraine, Moldova and Georgia). Operationally, these two big organisations are incomparable and perhaps even incompatible. Therefore, their respective members may be at odds inside the CDC grouping. There is a real possibility that one member may not be able to accommodate its commitments within the CIS (a regional body promoted by Russia) in the same basket with those within the CDC (an organisation of political entities where the EU is informally and sometimes ambivalently understood as a model (Rosamond 2004:61) or even a role-model). For example, Ukraine's recent multi-vector symbiotic foreign policy did not make it easier for the country to establish a firm decision whether to join NATO or not and get the same reaction from the CIS, the CDC, and even from its own citizens. However, the CDC-related activities may provide a testing ground to challenge "domestic political pressures in foreign policies" (Pedersen:16).

Every signatory of the CDC is a post-communist country which gained its independence in a complicated period and after series of groundbreaking events in the contemporary history of Europe. Undeniably, the CDC was established at a time when the EU is in demand on the stage of international politics (Ortega 2004:117). At present, about 37 per cent of the CDC area is already in the EU, and 
represents about 10 per cent of the Union's territory and 6.4 per cent of its population. In this context, and according to the EU's High Representative Javier Solana (2007), "the EU has not been designed to be a fortress". As such, the emergence of the CDC can be treated as a new development in the ongoing process of European integration, a process that often encourages "a greater degree of regional mobilisation" (Le Galès and Lequesne 1998:viii). In such process both the EU Member States and non-EU countries can find exciting opportunities to make the European continent irreversibly democratic and more cohesive.

\author{
Addresses: \\ Vlad Vernygora \\ National Centre for Research on Europe \\ University of Canterbury \\ Christchurch, New Zealand \\ Tel.: +649979 3126 \\ E-mail: vav13@student.canterbury.ac.nz \\ Natalia Chaban \\ National Centre for Research on Europe \\ University of Canterbury, Christchurch \\ New Zealand \\ Tel: +64 33642987 (extension 4912) \\ E-mail: natalia.chaban@canterbury.ac.nz
}

\title{
References
}

Adamkus, Valdas and Lech Kaczynski (2006) "For an ambitious vision of solidary and global Europe". Frankfurter Allgemeine Zeitung fur Deutschland. 12 July. Available from President of the Republic of Poland Official Website <http://president,pl/x.node?id=6042757>.

Băsescu, Traian (2007) "Address following accession to the plenary of the European Parliament". 31 January. Available from the Official Website of the President of Romania <http://www. presidency.ro/?_RID $=$ det $\&$ tb $=$ date $\& i d=8441 \& \_P R I D=a g>$.

Bezhuashvili, Gela (2006) "Message from the minister". Available from the Ministry of Foreign Affaires of Georgia Official Website <http://www.mfa.gov.ge/?sec_id=115\&lang_id=ENG〉.

Bērziņš, Indulis (2007) "Interview with co-author". 21 May, Christchurch, New Zealand.

Bremmer, Ian and Ray Taras (1993) Nation and politics in the Sovietsuccessor states. Cambridge and New York: Cambridge University Press.

Bukkovol, Tor (1997) Ukraine and European security. London: Royal Institute of International Affairs.

Chimisso, Cristina (2003) "What is identity". In Exploring European identities. Book 1 of the OU course AA (ZX) 300 Europe: culture and identities in a contested continent, 5-66. C. Chimisso, ed. Milton Keynes: The Open University.

Crvenkovski, Branko (2007) "Address at the general debate of the 62nd session of the general assembly of the United Nations". 25 September, New York, USA. Available from <http://www.un.org/webcast/ga/62/2007/pdfs/macedonia-en.pdf>.

Dembinski, B. (1941) "The age of Stanislas Augustus and the national revival". In The Cambridge history of Poland. Volume 2. W. F. Reddaway, J. H. Penson, O. Halecki, and R. Dyboski, eds. London: Cambridge University Press.

Dreifelds, Juris (1996) Latvia in transition. Cambridge; New York: Cambridge University Press. 
Dudwick, Nora (1993) “Armenia: the nation awakens”. In Nation and politics in the Soviet successor states, 261-288. I. Bremmer and R. Taras, eds. New York: Cambridge University Press.

Freire, Maria Raquel (2004) "The search for innovative procedures: the OSCE Approach to conflicts in the former Soviet area". In Sovereignty and the global community: the quest for order in the international system, 195-219. H. M. Hensel, ed. Aldershot, Hants, and Burlington, VT: Ashgate.

Galaka, Sergiy P. (2002) "Nuclear-weapon free Ukraine: between the two poles of power". In New security challenges in postcommunist Europe: securing Europe's east, 83-97. A. Cottey and D. Averre, eds. Manchester and New York: Manchester University Press.

Gerner, Kristian (1999) "Regions in Central Europe under communism". In Regions in Central Europe: the legacy of history, 178-210. S. Tägil, ed. London: Hurst \& Company.

Gullberg, Tom (1999) "The primacy of the nation and regional identity". In Regions in Central Europe: the legacy of history, 147-177. S. Tägil, ed. London: Hurst \& Company.

Haas Ernst B. (1997-2000) Nationalism, liberalism, and progress. 2 Vols. Ithaca and New York: Cornell University Press.

Hanggi, Heiner, Ralf Roloff, and Jürgen Ruland (2006) "Interregionalism: a new phenomenon in international relations". In Interregionalism and international relations, 3-15. H. Hanggi, R. Roloff, and J. Ruland, eds. New York: Routledge.

Herrmann, Richard and Marilynn B. Brewer (2004) "Identities and institutions: becoming European in the EU". In Transnational identities: becoming European in the EU, 1-22. R. K. Herrmann, T. Risse, and M.B. Bremer, eds. Lanham, MD: Rowman \& Littlefield.

Het'manchuk, Olena (2006) "Prydnistrov'ja: Nezaležni z Rosijeyu” (“Придністров' я: Незалежні 3 Росією”). Dzerkalo Tyždnja (Дзеркало Тижня), Issue 35 (614), 16-22 September. Available in Ukrainian from <http://www.dt.ua/1000/1600/54521/>.

Holland, Martin (2002) The European Union and the third world. Palgrave.

Hunter, Shireen (1993) "Azerbaijan: search for identity". In Nation and politics in the Soviet successor states, 225-260. I. Bremmer and R. Taras, eds. New York: Cambridge University Press.

Illarionov, Andrei (2005) Interview by Yuri Zarakhovich, "Putin's Critical Adviser". Time, 31 December. Available from <http://www.time.com/time/world/article/0,8599,1145192,00.html>.

Johnson, Lonnie R. (1996) Central Europe: enemies, neighbors, friends. New York, Oxford: Oxford University Press.

Jones, Barry (1985) "Conclusion". In Regions in the European community, 234-245. M. Keating and B. Jones, eds. Oxford, Oxfordshire: Clarendon Press; New York: Oxford University Press.

Keating, Michael (1988) State and regional nationalism: territorial politics and the European states. Harvester Wheatsheaf.

Keating, Michael (1998a) "Is There a regional level of government in Europe". In Regions in Europe, 11-29. P. Le Galès and C. Lequesne, eds. London; New York: Routledge.

Keating, Michael (1998b) The new regionalism in western Europe: territorial restructuring and political change. Cheltenham, UK, Northampton, MA: Edward Elgar.

King, Charles (2004) "Is the Black Sea a region". In The Black Sea region: cooperation and security building, 13-26. O. Pavliuk and I. Klympush-Tsintsadze, eds. Armonk, New York: M.E. Sharp.

Kolbre, Priit (2005) as quoted in EU enlargement - one year on, the proceedings of an international conference hosted by Audentes University, 22 April 2005, Tallinn, Estonia. A. Charles, ed. Audentes University in cooperation with the British Council.

Laffan, Brigid (2004) "The European Union and its institution as 'identity builders"'. In Transnational identities: becoming European in the EU, 75-96. R. K. Herrmann, T. Risse, and M. B. Bremer, eds. Lanham, MD: Rowman \& Littlefield.

Langenhove, Luk van and Ana-Cristina Costea (2007) "EU' foreign ppolicy identity: from 'new regionalism' to third generation regionalism". In European Union identity: perceptions from Asia and Europe 86-104. J. Bain and M. Holland, eds. Baden-Baden: Nomos.

Le Galès, Patrick and Christian Lequesne (1998) "Editors' preface". In Regions in Europe. P. Le Galès and C. Lequesne, eds. London; New York: Routledge. 
Lein-Mathisen, Jorn (2004) "Nordic regional lobbying in Brussels". In The Nordic region and the European Union, 93-114. S. Dosenrode and H. Halkier, eds. Ashgate.

Misiunas, Romuald J. and Rein Taagepera (1993) The Baltic states: years of dependence, 1940 1990. London: Hurst.

Makhmudov, Emin and Mikhail Zygar (2005) "Revolution in the pipeline". Kommersant, 25 May. Available from <http://www.kommersant.com/page.asp?id=580345>.

Major, John (1992) "Text of speech made in the debate on the European Community in the House of Commons", presented 20 November 1991, London, England. In "Annexes" of The intergovernmental conference on political union: institutional reforms, new policies, and international identity of the European community, F. Laursen and S. Van Hoonacker, eds. Holland, Maastricht: European Institute of Public Administration.

Meller, Stefan (2006) "Po co Europie Ukraina?". WIEŻA CIŚNIEŃ, supplement to Gazeta Wyborcza Wroctaw, Issue 274, 24 November, 6. Available in Russian from <http://www. korrespondent.net/main/171576/>.

Mizsei, Kalman (on behalf of Kofi Annan, 2005) "Community of democratic choice". Statement made 2 December, Kyiv, Ukraine. Available from UNPD Official Website $\langle\mathrm{http} / / /$ europeandcis.undp.org/?menu=p_article\&ArticleID=256>.

Moravcsik, Andrew (1998) The choice for Europe: social purpose and state power from Messina to Maastricht. Ithaca, New York: Cornell University Press.

Mostova, Yulija (2007) “Šče Raz Pro Deševyj Syr”. Dzerkalo Tyždnja, Issue 5 (634), 10-16 February. Available in Ukrainian from <http://www.dt.ua/1000/1030/55839/>.

Motyl, Alexander and Bohdan Krawchenko (1997) "Ukraine: from empire to statehood". In New states, new politics: building the post-Soviet nations, 235-275. I. A. Bremmer and R. Taras, eds. Cambridge; New York: Cambridge University Press.

Nahaylo, Bohdan (1999) The Ukrainian resurgence. London: Hurst \& Company.

Newhouse, John (1997) “Europe's rising regionalism”. Foreign Affairs, January-February. Available from <http://www.foreignaffairs.org/19970101faessay3740/john-newhouse/europe-s-risingregionalism.html>.

Ortega, Martin (2004) "Conclusion: 'region-building' in Europe and across the world". In Global views on the European Union,117-130. M. Ortega, ed. (Chaillot Paper, 72.) Paris: Institute for Security Studies.

Pallum, Priit (2007) "Interview with co-author". 25 July, Tallinn, Estonia

Pavliuk, Oleksandr (2004) "Introduction". In The Black Sea region: cooperation and security building, 3-12. O. Pavliuk and I. Klympush-Tsintsadze, eds. Armonk and New York: M.E. Sharp.

Pedersen, Thomas (1998) Germany, France, and the integration of Europe: a realist interpretation. London; New York: Pinter.

Prizel, Ilya (1998) National identity and foreign policy: nationalism and leadership in Poland, Russia and Ukraine. Cambridge, UK; New York: Cambridge University Press.

Robinson, Neil (2004) "Chapter 7. The Post-Soviet Space”. In The New Regional Politics of Development. A. Payne, ed. 169-192, Houndmills, Basingstoke, Hampshire; New York: Palgrave Macmillan.

Rosamond, Ben (2004) "Chapter 3. Europe". In The New Regional Politics of Development. A. Payne, ed. 59-88, Houndmills, Basingstoke, Hampshire; New York: Palgrave Macmillan.

Telo, Mario (2006) Europe: a civilian power? European Union, global governance, world order. New York: Palgrave Macmillan.

Socor, Vladimir (2006) "Moscow fingerprints all over South Ossetia's referendum". Eurasia Daily Monitor 3, 212, 15 November. Available from <http://www.jamestown.org/edm/ article.php?article_id=2371648>.

Solana, Javier (2007) "Interview to Dzerkalo Tyždnja". Isue 34 (663), 15-21 September. Available from <http://www.mw.ua/1000/1550/60477/> or <http://www.consilium.europa.eu/ueDocs/ cms_Data/docs/pressdata/EN/sghr_int/95968.pdf >. 
Szczerbiak, Alex (2004) "Polish Euroscepticism in the run-up to the EU accession". In Euroscepticism: party politics, national identity and European integration, 247-268. R. Harmsen and M. Spiering, eds. Amsterdam; New York: Rodopi.

Wagstyl, Stefan and Roman Olearchyk (2007) "Their Ukraine". The Financial Times, 15 June. Available from <http://www.ft.com/cms/s/5530e68c-1adc-11dc-8bf0-000b5df10621.html>.

Wallace, Helen (2002) "Europeanisation and globalisation: complementary or contradictory trends". In New Regionalism in the Global Political Economy. Theories and Cases, 137-150. S. Breslin, C.W. Hughes, N. Phillips, and B. Rosamond, eds. London; New York: Routledge. 